\title{
HUBUNGAN KOMUNIKASI DAN KEPEMIMPINAN TERHADAP KINERJA PENGAWAI KANTOR SISTEM ADMINISTRASI MANUNGGAL SATU ATAP KABUPATEN BIREUEN
}

\author{
Cut Khairani $^{\left.1^{* *}\right)}$ dan Hakim Muttaqim ${ }^{2 *}$ \\ ${ }^{1)}$ Fakultas Ilmu Sosial dan Ilmu Politik Universitas Almuslim \\ 2) Fakultas Ekonomi, Universitas Almuslim \\ ${ }^{*}$ Email: cut.fisip13@gmail.com dan hakimmuttaqim11@gmail.com
}

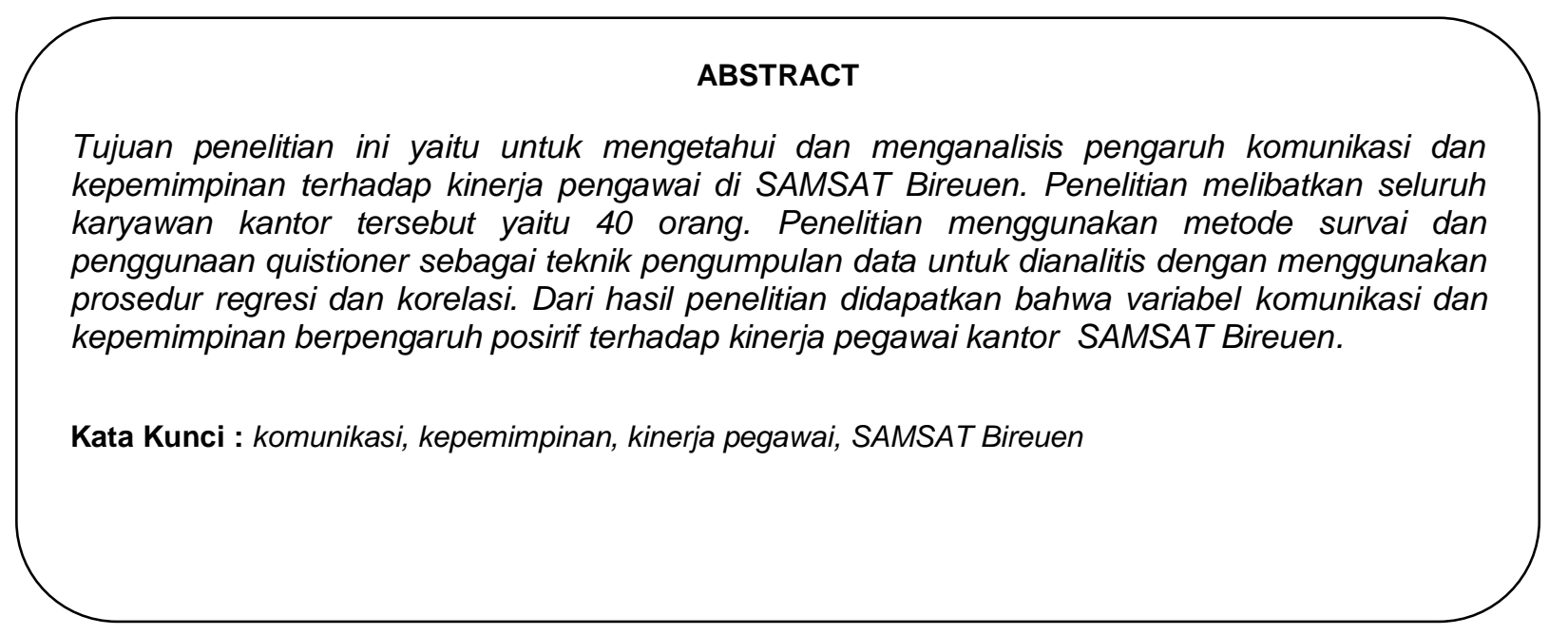

\section{Pendahuluan}

Jumlah penduduk yang terus meningkat setiap tahunnya memberikan dampak pada kebutuhan akan alat transportasi yang digunakan. Peningkatan jumlah kendaraan bermotor yang cukup signifikan yaitu 6,36 persen per tahun. Peningkatan jumlah kendaraan terjadi pada semua jenis kendaraan setiap tahunnya. Kenaikan jumlah kendaraan bermotor yang cukup tinggi terjadi pada sepeda motor yaitu 6,20 persen per tahun (BPS, 2019), sehingga dalam hal ini membutuhkan administrasi untuk kendaraan yang dilakukan oleh instansi pemerintah yaitu Kantor Bersama Sistem Administrasi Manunggal Satu Atap (SAMSAT) yang salah satunya bertujuan untuk meningkatkan kualitas pelayanan kepada masyarakat. Dalam penerapannya adanya penurunan hasil yang diperoleh melalui pendapatan asli daerah, sehingga penting untuk dicermati, hal ini relevan dengan terjadinya penurunan kinerja pegawai pada SAMSAT Bireuen.

Kinerja yang merupakan perilaku nyata yang ditampilkan oleh setiap orang sebagai prestasi kerja yang dihasilkan oleh karyawan sesuai dengan perannya dalam perusahaan (Rivai \& Aderito, 2013). Sehingga untuk meningkatkan kinerja pegawai yaitu tentang komunikasi yang dimiliki oleh pegawai tersebut. Wiryanto (2012) mengungkapkan bahwa Komunikasi merupakan pengiriman dan penerimaan berbagai peran organisasi didalam kelompok formal maupun informal. Kinerja dipengaruhi oleh faktor tertentu, faktor-faktor yang mempengaruhi kinerja pengawai yaitu kemampuan dan keahlian, pengetahuan, rancangan kinerja, kepribadian, motivasi kerja dan kepemimpinan.

Kepemimpinan merupakan kekuatan, semangat, kemampuan yang dimiliki seseorang yang dapat mempengaruhi orang lain yang mengikuti hasil pemikirannya atau mengerjakan apa yang diharapkan sebagaimana yang telah ditentukan (Slamet, 2007). Fenomena kepemimpinan dikantor pajak SAMSAT Bireuen yaitu, kurangnya kemampuan seorang pemimpin dalam mengambil keputusan, kurangnya kemampuan memberi motivasi kerja kepada pengawai dikantor dan kurang kemampuan dalam mengendalikan bawahannya. Sehingga pengawai dikantor merasa tidak dikendalikan atau tidak diarahkan dengan baik oleh pemimpin disana. Selain itu, kualitas pegawai juga banyak yang tidak tepat waktu datang ke kantor, dan juga kehadiran yang kurang dianggap penting oleh banyak pengawai, bahkan ada pengawai yang tidak 
hadir lebih dari 3 hari tanpa ada keterangan yang pasti, \& Hamzah, 2018)

\section{Metodelogi}

Penelitian ini menggunakan metode kuantitatif. Desain penelitian kuantitatif merupakan metode-metode untuk menguji teori-teori tertentu dengan cara meneliti hubungan antar variabel (Creswell, 2013) Aspek kuantitatif yang ditekankan disini pada pengukuran secara objektif terhadap fenomena sosial dalam suatu populasi. Fenomena sosial yang terjadi dijabarkan dalam komponen permasalahan, variabel dan indikator. Setiap variabel yang akan diukur disajikan dalam simbol-simbol berupa angka yang berbeda sesuai dengan maksud variabel tersebut. Angka-angka yang merupakan symbol dari kondisi sosial yang didapatkan kemudian disusun dan dianalisis dengan teknik perhitungan secara kuantitatif matematis sehingga dapat digunakan untuk menarik sebuah kesimpulan (Sumanto, 1995).

Sampel dalam penelitian ini adalah seluruh pengawai dan pimpinan pada kantor pajak SAMSAT Bireuen yang berjumlah 40 orang. Teknik pengumpulan data yang digunakan yaitu dengan wawancara, kuesioner, observasi dan gabungan ketiganya. Metode analisis data yang digunakan yaitu analisis deskriptif digunakan untuk menggambarkan mengenai fakta-fakta yang ada secara faktual dan sistematis. Metode yang digunakan adalah sebagai berikut : hasil pengoperasian variabel disusun dalam bentuk pertanyaan pertanyaan (kuesioner/angket). Dimana Komunikasi (variabel X1), Kepemimpinan (variabel X2) dan Kinerja Pegawai (variabel Y), setiap item dari kuesioner tersebut memiliki lima jawaban dengan bobot/nilai yang berbeda. Yang kemudian dilakukan uji statistik untuk melihat pengaruh dari setiap variabel.

\section{Hasil dan Pembahasan \\ Validitas, dan Reabilitas Data}

Berdasarkan hasil uji validitas dan realiabilitas data, maka seluruh item pernyataan dalam setiap variabel independen (komunikasi, dan kepemimpinan), terhadap variabel dependen (kinerja pegawai) memiliki korelasi diatas 0,2673 sebagai nilai batas suatu item kuisioner penelitian dapat diterima, sehingga dapat dikatakan bahwa setiap item pernyataan dalam kuisinoner masing-masing variabel tergolong valid dan dapat digunakan untuk mengukur variabel yang diteliti. Demikian juga dengan uji reliabilitas yang menghasilkan koefisien reliabilitas instrument terhadap variabel komunikasi sebesar 0,758 , faktor epemimpinan 0,806 dan kinerja pegawai 0,775. Hasil analisis menunjukkan nilai Cronbach Alpha's lebih besar dari 0,60 yang berarti instrument dinyatakan reliabel atau memenuhi persyaratan.

\section{Pengaruh Komonikasi dan Kepemimpinan Terhadap Kinerja}

Analisi regresi berganda bertujuan untuk menganalisi dan mengetahui pengaruh variabel komunikasi dan kepemimpinan terhadap kinerja pegawai pada kantor pajak SAMSAT Bireuen, atau pengaruh dari variabel indenpenden terhadap variabel dependen. Hasil analisis regresi antar variabel diperoleh persamaan regresi linier berganda sebagai berikut yaitu: $Y=0,106+0,868 X_{1}+0,118 X_{2}(P$ $0,00)$. Dari persamaan di atas dapat dijelaskan bahwa nilai konstan (intersep) adalah 0,106 artinya jika komunikasi dan kepemimpinan dianggap konstan (nol), maka nilai komunikasi dan kepemimpinan pada kantor pajak Samsat Bireuen meningkat sebesar $1,06 \%$. Secara prasial faktor komunikasi berpengaruh nyata terhadap kinerja karyawan SAMSAT Bireuen ( $P$ 0,00 ), demikian pula pengaruh faktor kepemimpinan dengan nilai signifikansi 0,031. Kominikasi dan kepemimpinan yang berlangsung dalam organisasi SAMSAT Bireuen memberi efek pisitif terhadap kinerja karyawan pada kantor tersebu.

Koefisien determinasi digunakan untuk mengukur seberapa besar persentase perubahan atau variasi dari variabel dependen bisa dijelaskan oleh perubahan atau variasi dari variabel indenpenden. Semakin tinggi nilai koefisien determinasi akan semakin baik kemampuan variabel indenpenden dalam menjelaskan pengaruhnya terhadap variabel dependen. Hasil pengujian koefisien determinasi dapat dilihat dari nilai adjusted $R$ square pada analisis regresi berganda yaitu sebesar 0,859. Nilai ini menunjukkan bahwa keragaman kinerja pegawai SAMSAT Bireuen dapat dijelaskan oleh faktor komunikasi dan kepemimpinan sebesar 85,9 \%, sedangkan sisanya sebesar $14,1 \%$ dapat dijelaskan oleh variabel lain yang tidak termasuk dalam variabel independen dalam penelitian ini. Adapun nilai hubungan (koefisien korelasi) antara faktor komunikasi dan kepemimpinan terhadap kinerja karyawan kantor SAMSAT Bireuen tergolong erat yaitu 0,931.

Komunikasi adalah penyampaian atau penerimaan pesan dari satu orang kepada orang lain, baik lansung maupun tidak lansung, secara tertulis, lisan maupun bahasa nonverbal. Orang yang melakukan komunikasi 
disebut dengan komunikator. Orang yang mampu berkomunikasi secara efektif disebut komunikatif. Orang yang komunikatif ialah orang yang mampu menyampaikan informasi atau pesan kepada orang lain, baik lansung maupun secara tidak lansung, baik tertulis, lisan maupun nonverbal sehingga orang lain dapat menerima informasi sesuai dengan harapan si pemberi informasi. Komonikasi ternyata menimbulkan pengaruh positif terhadap kinerja karyawan pada kantor SAMSAT Bireuen. Hal ini dapat terjadi akibat terbukanya semua saluran komunikasi dan berkurangnya dampak miskomunikasi dalam pelaksanaan instraksi dalam organisasi terdsebut (Sariani, 2019). Kepemimpinan yang berlangsung dalam kantor SAMSAT Bireuen juga memberikan pengaruh positif terhadap kinerja karyawan kantor tersebut. Hal ini diduga karena kepemimpinan (leadership style) menjadi sumber motivasi bagi karyawan untuk bekerja keras sesuai ketentuan yang berlaku. Sesuai dengan hasil penelitian Suwarno, dan Bramanty (2019), bahwa gaya kepemimpinan yang dilakukan bersumber pada hati nurani, nilai-nilai norma, etika, kebebasan, pemberian kepercayaan, pengawasan, siap menerima kritik, saran yang bersifat membangun, tegas dan menghormati kreativitas, inovasi dan motivasi.

\section{Kesimpulan}

Faktor Komunikasi yang berlangsung antar karyawan SAMSAT Bireuen berpengaruh positif terhadap kinerja kantor tersebut, demikian pula kepemimpinan masing-masing unit dilingkungan SMSAT memberi pengaruh yang sama terhadap kinerja karwanan. Hubungan antara Komunikasi dan kepemimpinan dengan aspek kinerja karyawan berlangsung dalam bentuk hubungan yang tergolong erat (r 0,931).

\section{Daftar Pustaka}

Creswell, W. John. 2013. Research Design Pendekatan Kualitatif, Kuantitatif, dan. Mixed. Yogyakarta : Pustaka Pelajar. Departemen Kesehatan Republik Indonesia, Jakarta

Rivai, Aderito. 2013. Manajemen Sumber Daya Manusia untuk Perusahaan dari Teori ke Praktik. Jakarta : PT. Raja Grafindo.

Sariani, N.,L., P. 2019. Strategi Komunikasi Dalam Meningkatkan.Kinerja Karyawan
Di Bhr Law Office. Jurnal IImiah Manajemen dan Bisnis, 4(2): 115-124

Slamet, S, 2007, Kumpulan Bahan Kulaih Mata Kuliah Organisasi Dan Kepemimpinan, Bogor: Institute Pertanian Bogor

Sumanto. M.A. 1995. Metodologi Penelitian Sosial Dan Pendidikan. Yogyakarta. : Andi Offset

Suwatno. 2001. Asas-Asas Manajemen Sumber Daya Manusia. Bandung: Penerbit Suci Press

Wiryanto. 2012. Pengantar ilmu komunikasi. Jakarta : PT Grasindo 